\title{
CORRIGENDA
}

\section{Corrigenda: Activation of mGlu2/3 receptors as a new approach to treat schizophrenia: a randomized Phase 2 clinical trial}

Sandeep T Patil, Lu Zhang, Ferenc Martenyi, Stephen L Lowe, Kimberley A Jackson, Boris V Andreev, Alla S Avedisova, Leonid M Bardenstein, Issak Y Gurovich, Margarita A Morozova, Sergey N Mosolov, Nikolai G Neznanov, Alexander M Reznik, Anatoly B Smulevich, Vladimir A Tochilov, Bryan G Johnson, James A Monn \& Darryle D Schoepp

Nat. Med. 13, 1102-1107 (2007); published online 2 September 2007; corrected after print 17 September 2007

In the version of this article initially published, the name of one person acknowledged was misspelled, and reference 4 should have been:

Moghaddam, B. \& Adams, B.W. Reversal of phencyclidine effects by a group II metabotropic glutamate receptor agonist in rats. Science 281, 1349-1352 (1998).

These errors have been corrected in the HTML and PDF versions of the article. 